\title{
On-farm Conservation of Zaer Lentil Landrace in Context of Climate Change and Improved Varieties Competition
}

\author{
Nadia Benbrahim*, Mona Taghouti, Abdelmajid Zouahri, Fatima Gaboun \\ National Institute of Agricultural Research (INRA), BP 6570, Rabat-Institutes, Morocco
}

Copyright $\mathrm{C} 2017$ by authors, all rights reserved. Authors agree that this article remains permanently open access under the terms of the Creative Commons Attribution License 4.0 International License

\begin{abstract}
Lentil (Lens culinaris Medik.) landrace of Zaer had been on-farm conserved thanks to ingenious farmers' practices. Farmers had selected, produced and maintained their landrace to satisfy their food security, ecological and economical needs. However, the increase of drought incidence had encouraged farmers to gradual abandonment of their landrace for $\mathrm{L}_{56}$ improved variety to increase productivity and incomes. The landrace is therefore threatened for genetic drift by climatic change, varieties innovation and economic development. The main objective of this study is to strengthen the on farm conservation of lentil landrace of Zaer through its promotion under a distinctive sign of origin and quality in accordance with national agricultural policy. Thus, the investigation is focused on analyzing (i) farmers' knowledge through field survey of 41 farmers randomly chosen across Zaer region, (ii) genetic structure of landrace as meta-population and by four geographical locations using biochemical markers (SDS-PAGE), and (iii) genetic relationship between the landrace and $\mathrm{L}_{56}$ improved variety cultivated in Zaer. Data analysis had provide us with valuable information's on seed management according to climate and farmers' category, genetic structure of landrace as meta-population which was shaped by both natural pressures and human practices, and on seeds flow between landrace and $\mathrm{L}_{56}$ variety that might be linked to seed acquisition, spatial organization of production field or to post-harvest seed management.
\end{abstract}

Keywords Lentil, Landrace, Variety, On-farm Conservation, Climate Change, Zaer-Morocco

\section{Introduction}

Legumes crop provide many ecosystem services towards a sustainable farming system thanks to their ability to fix symbiotic nitrogen and to improve soil health and functionality through improving soil texture. Grain legumes are also an important source of dietary protein and essential minerals. They may contribute to food security thanks to their highly nutritious seed products.

Lentil (Lens culinaris Medik) is one of the main food legumes produced widely in the world for its agro-ecological and nutritional interest [1]. It is usually grown in rainfall and semi-arid areas receiving an annual average of 300-400 mm [2]. In Morocco, lentils are mainly produced by landraces through traditional farming system in low potential lands mainly by smallholder farming. Landraces had been selected by farmers through generations for grain quality and for production stability under traditional low input agricultural system, diverse and adverse environments [3-4]. Landraces specific and dynamic adaptation potential might be linked to their genetic diversity and agricultural practices interaction. Many studies suggested that landraces are composed of a large amount of allelic variation [5-6]. They are composed of several genotypes able to yield in varying biotic and environmental constraints. Therefore, they are maintained to minimize risk of crop failure thanks to their resilience under less optimal growing conditions. Landraces satisfy farmer's food and socio-economical needs, and they are appreciated for their tasty quality and cooking ability.

Indeed, many studies showed that modern varieties provide a lower significant yield advantage than landraces in unfavorable environment [7-8]; whereas landraces productivity might increase in favorable environment according to Pecetti et al, [9] study on durum wheat and to Ceccarelli et al, [8] study on barley. Thereby, landraces potential value is evident in conserving plant genetic diversity for improving human food security and enhancing livelihoods of small farmers. Furthermore, landraces are potential and valuable genetic sources of beneficial traits that can be used to confer pest and disease resistance and yield stability [6]. There might provide breeders with available genes or elite genotypes to be used in breeding programs.

Feeding population with safe and nutritional food, improve farmers' income to reduce rural-urban migration, protect and conserve natural resources and integrate agriculture in national and international markets were the greatest challenge of Moroccan agricultural strategy "Green Moroccan Plan (GMP)" [10]. GMP is based on two pillars; Pillar-I concerning development of modern agriculture and 
pillar-II concerning strategies to provide support to farming family that concern a several thousand farms. GMP expectations is to increase food legumes production by 40 to $80 \%$ at 2020 horizon through technology transfer, optimization and sustainable seed management, labelling high quality product and integration of worldwide markets.

In this context, the following study was based on lentils of Zaer region in Morocco, produced from both a landrace and $\mathrm{L}_{56}$ variety. It focused on (i) farmer's knowledge related to seed management system as an effective support for the on-farm conservation, farmers' decisions according to socio-economic factors and seed exchange, (ii) genetic structure of Zaer lentils using biochemical markers (SDS-PAGE), and (iii) assessing the effect of climate change and variety innovation on on-farm conservation of the landrace.

\section{Material and Methods}

The current study was carried on lentil landrace of Zaer. It was based on a survey during 2012 season from 41 farmers randomly chosen across lentil production area in Zaer region. Four localities had been concerned by the survey: Ain Sbit (O6 $\left.{ }^{\circ} 48, \mathrm{~N}^{\circ} 3^{\circ} 52\right)$, Jamaât Moulblad (O643, N3358), Aghbal $\left(\mathrm{O}^{\circ} 52, \mathrm{~N} 33^{\circ} 60\right)$ and Brachoua $\left(\mathrm{O} 6^{\circ} 62, \mathrm{~N}^{\circ} 3^{\circ} 65\right)$ (Figure 1). Zaer rainfall data had been collected from meteorological station located in Merchouch (Zaer) experimental station of National Institute of Agronomic Research (INRA). The analysis of those data had informed on climate variability in this region (Figure 3 ).

\subsection{Field Survey}

The questionnaire generates data on farming system, agricultural practices, farmers' agricultural equipment's, lands crops, varieties used, seed acquisition, main biotic and abiotic stresses, lentil productivity, post-harvest seed management, seed sell, seed stock, seed sanitary quality and lentil incomes. Data analyses of 30 variables were grouped together using clusters according to farmers' categories or to agricultural practices.

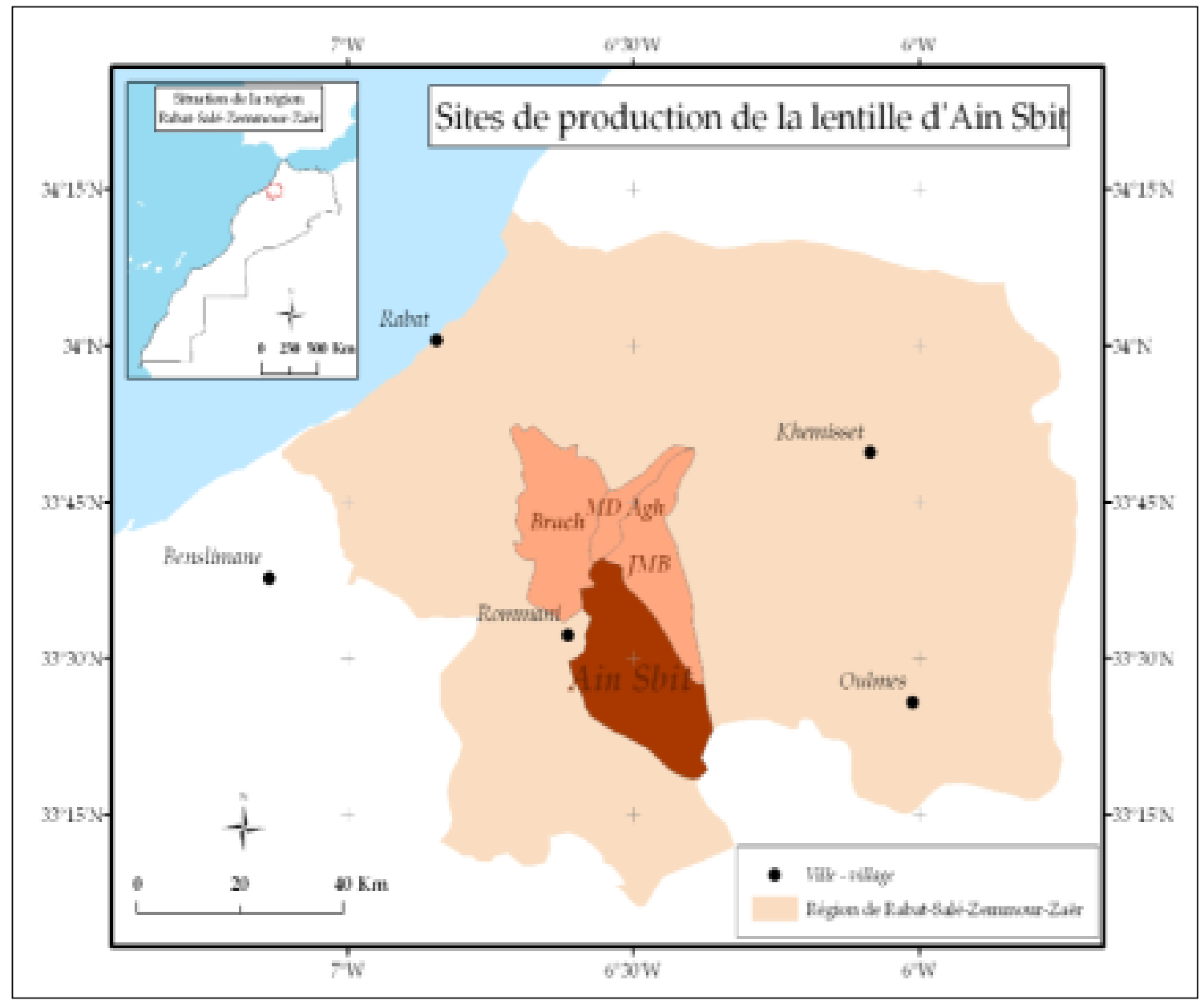

Figure 1. Zaer lentil geographical production area 


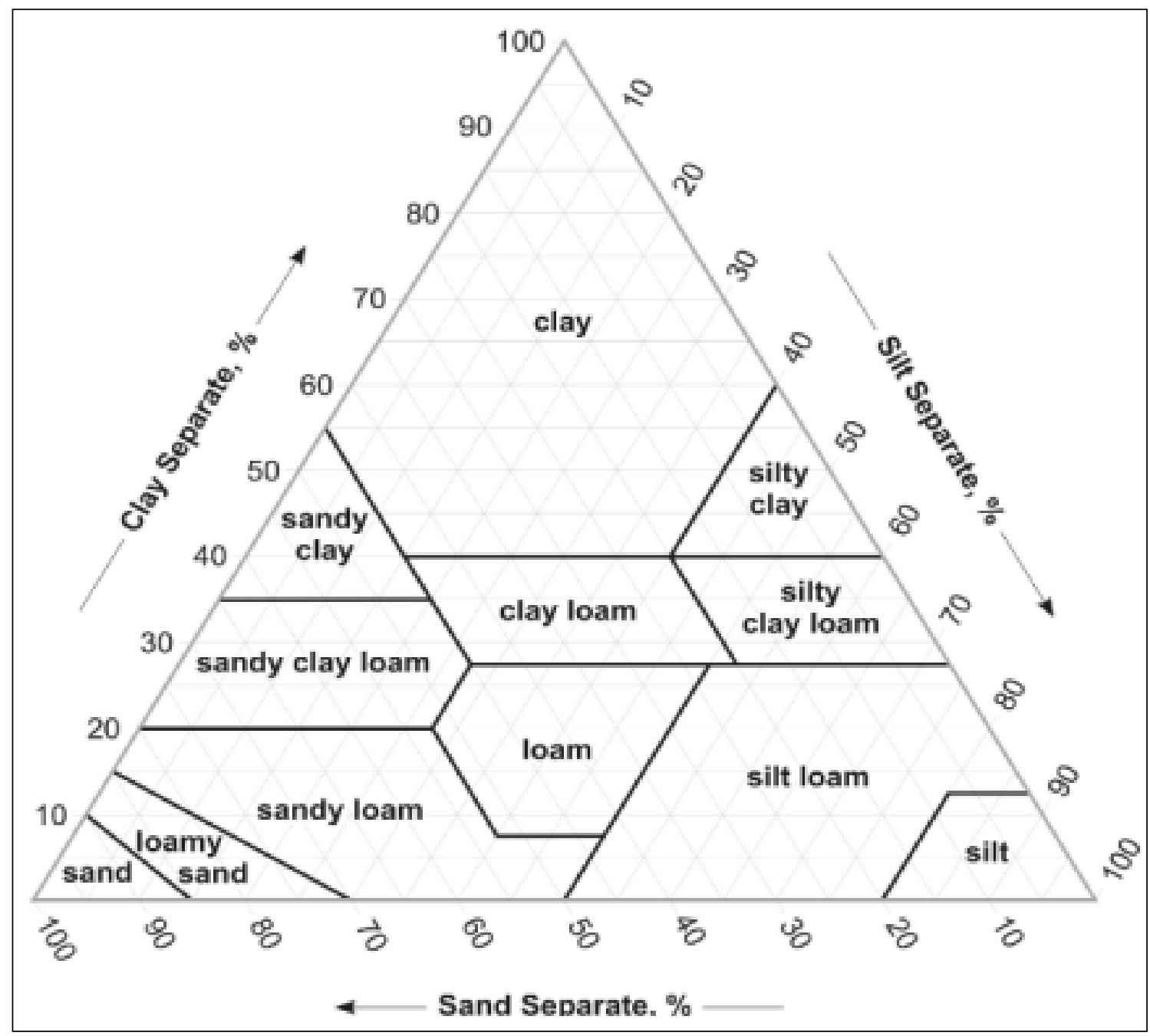

Figure 2. Diagram of USDA Soil texture triangle

\subsection{Field Experimentations}

During 2012/13 season, 24 farmers' field (accessions) was randomly selected across the four target localities of Zaer region. At field level, ten plants were randomly collected at $90 \%$ of seed maturity along field diagonal at regular intervals according to the standards reference in the practice guide of Marchenal [11]. In addition, samples of soil collected in prospected fields from 5 to $15 \mathrm{~cm}$ deep were analyzed for soil granulometry, minerals and organic composition and for soil acidity. Soil granulometry analysis has concerned the fine soil particle size $(0-2 \mathrm{~mm})$. This is divided into three particles size classes related to clay $(0-2 \mu \mathrm{m})$, silt $(2-20 \mu \mathrm{m})$ and sand $(20-2000 \mu \mathrm{m})$. Soil texture of Zaer was determined using the USDA soil texture diagram (Figure 2). It is based on sand, silt and clay fractions present in each sample of Zaer soil and on particles size of sand and clay according to Soil Survey Manual [12]. The USDA soil texture diagram leads to twelve major soil texture classes related to sand and clay proportion (Figure 2).

\subsection{Genetic Diversity Analysis}

Three plants randomly chosen from the ten plants collected was assessed using sodium dodecyl sulfate polyacrylamide gel electrophoresis (SDS-PAGE) as described by Laemmli [13]. One grain per plant was chosen and was analyzed individually. Total proteins were extracted using buffer of $0.3 \mathrm{M}$ Tris / HCl (pH 6.8), $1 \%$ SDS, $0.3 \%$ of 2 -mercapto-ethanol and $8 \%$ glycerol (weight/volume ratio of $1: 20)$. Seed protein extracts were analyzed by a vertical slab gel in a discontinuous buffer system [13], and to which $10 \mu \mathrm{L}$ protein extract solution in $14 \%$ polyacrylamide gel was loaded. Proteins in gels were stained with $0.1 \%$ Coomassie blue, $50 \%$ methanol and $10 \%$ acetic acid. Molecular weights of the dissociated polypeptides were evaluated with molecular weight protein marker (8KDa-220KDa). Proteins bands were scored 1 or 0 depending on their presence or absence in the electrophoretic profile. The scoring was based on 23 bands reproducible in the high-protein variation area of the electrophoretic profile between $65 \mathrm{KDa}$ and $30 \mathrm{KDa}$.

\subsection{Statistical Analysis}

The analysis of molecular variance (AMOVA) was used 
to assess the genetic diversity within the meta-population and between populations by spatial scale (site) [14]. Genetic diversity was calculated including number of different alleles $(\mathrm{Na})$, number of effective alleles $\left(\mathrm{Ne}=1 /\left(\mathrm{p}^{2}+\mathrm{q}^{2}\right)\right)$, Shannon-Weaver's Index $(S W I=-1(p \operatorname{Ln}(p)+q \operatorname{Ln}(q))[15]$, expected heterozygosity $(\mathrm{He}=2 \mathrm{pq})$, unbiased expected heterozygosity $(\mathrm{UHe}=(2 \mathrm{~N} /(2 \mathrm{~N}-1)) \mathrm{He})$, and the percentage of polymorphic loci $(\% \mathrm{P})$. All the measurements were assessed and represented as mean and standard error (SE) over loci within the meta-population and over loci between populations. The genetic difference (PhiPT), Nei genetic identity index (NeiGI) and Nei genetic distance index (NeiGD) [16] were calculated between pairwise populations (site) as the proportion of the variance among populations relative to the total variance. The SDS-PAGE data were also subjected to a hierarchical cluster (Cluster) built on the basis of genetic distances calculated by GenStat using Jaccard similarity and dissimilarity index among accessions [17].

\section{Results and Discussion}

\subsection{Agro-ecological Environment of Zaer Region}

Zaer is the second important lentil production region in Morocco which provides $32 \%$ of lentil national production [18]. Zaer lentil geographical area is delimited by lentil agronomic skills including four rural communities: Ain Sbit (ASb), Aghbal (Agh), Brachoua (Bch) and Jamâat Moulblad (JMB) [19].

\subsubsection{Soil Characteristics}

Lentil Zaer area is characterized by an ecological diversity including soil texture and topography. Data analysis of Zaer soil confirms soil variability according to its texture and mineral composition (Table 1). Soil texture is mainly Clay and Clay loam by location at Asb, JMB and Bch. It is also Clay loam to Loam and Loam at Asb, and Clay loam to Clay at Bch. Whereas at Agh, soil texture is Silty clay or Silty clay loam or Silty clay to Clay.

Three types of soil were observed at Zaer region according to their colors. Soil color of lentil fields is mainly red or brown and white by location. Red color indicates the presence of iron oxides, brown color indicates that soil contain a high level of organic matter (OM) while white color indicates that the soil is rich on calcite. Brown and red soils are more frequent than white soil. Brown soils are mainly frequent at Agh and Bch, while red soils are frequent at Asb and JMB. White soils are rare and mainly located at Bch and Asb that is approved by high level of $\mathrm{CaCO}_{3}$ in some locations. Red and brown soils are well drained and rich on oxygen while white soils are low drained and poor in oxygen. There are less sustainable to lentil crop.

The amount of organic matter in Zaer soil varied from less than $1 \%$ to $3.4 \%$. The low content of organic matter by locations makes lentil crop more susceptible to climatic variations. Phosphorus content in Zaer soil varied from 8.4 to $45.4 \mathrm{ppm}$. It might be related to the input of phosphate fertilizer which is linked to farmers' category. The low amount of phosphorus in the soil impacts root development, photosynthesis and therefore lentil seed production potential. Potassium amount of Zaer soil is also significantly variable across Zaer region (147-708 ppm). Soil analysis of Agh region shows a silty texture, an acidic soil which contains a low amount of organic matter and potassium (Table 1). Thus, Agh region is less suitable for lentil production compared to others sites of Zaer that is in accordance with farmers' statements.

Table 1. Soil characteristics of Zaer lentil area

\begin{tabular}{|c|c|c|c|c|c|c|}
\hline Site & Soil texture & Organic Matter (\%) & $\mathrm{pH}(\mathrm{KCl})$ & $\mathrm{P}_{2} \mathrm{O}_{5}(\mathrm{ppm})$ & $\mathrm{K}_{2} \mathrm{O}(\mathrm{ppm})$ & $\mathrm{CaCO}_{3}(\%)$ \\
\hline Asb & $\begin{array}{c}\text { Clay } \\
\text { Clay loam } \\
\text { Clay loam to Loam } \\
\text { Loam }\end{array}$ & $\begin{array}{c}\begin{array}{c}2.13 \pm 0.18 \\
(1.49-3.36)\end{array} \\
\text { Low to high OM content }\end{array}$ & 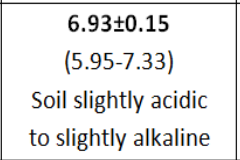 & $\begin{array}{c}23.0 \pm 3.84 \\
(8.4-45.4)\end{array}$ & $\begin{array}{l}451.2 \pm 46.8 \\
(225-708)\end{array}$ & $\begin{array}{c}9.95 \pm 2.18 \\
(2.81-23.4) \\
\text { Iron chlorosis risk by location } \\
(\mathrm{CaCO}>10 \%)\end{array}$ \\
\hline Bch & $\begin{array}{c}\text { Clay } \\
\text { Clay loam } \\
\text { Clay loam to Clay }\end{array}$ & $\begin{array}{c}1.81 \pm 0.21 \\
(0.98-2.26) \\
\text { Very low to low OM content } \\
\text { and by location high OM content }\end{array}$ & $\begin{array}{c}6.98 \pm 0.08 \\
(6.65-7.21) \\
\text { Soil neutral } \\
\text { to slightly alkaline }\end{array}$ & $\begin{array}{c}29.0 \pm 3.74 \\
(18.1-42.7)\end{array}$ & $\begin{array}{l}331.0 \pm 52.1 \\
(174-546)\end{array}$ & $\begin{array}{c}6.70 \pm 2.24 \\
(2.3-14.2) \\
\text { Iron chlorosis risk by location } \\
(\mathrm{CaCO}>10 \%)\end{array}$ \\
\hline JMB & $\begin{array}{c}\text { Clay } \\
\text { Clay loam }\end{array}$ & $\begin{array}{c}1.79 \pm 0.21 \\
(1.06-2.22) \\
\text { Very low to low OM content } \\
\text { and by location high OM content }\end{array}$ & $\begin{array}{c}6.77 \pm 0.13 \\
(6.42-7.00) \\
\text { Soil slightly acidic } \\
\text { to neutral } \\
\end{array}$ & $\begin{array}{c}17.7 \pm 3.17 \\
(10.3-23.2)\end{array}$ & $\begin{array}{l}375.8 \pm 43.6 \\
(294-495)\end{array}$ & $\begin{array}{l}4.18 \pm 1.10 \\
(2.3-7.2)\end{array}$ \\
\hline Agh & $\begin{array}{c}\text { Silty clay } \\
\text { Silty clay loam } \\
\text { Silty clay to Clay } \\
\end{array}$ & $\begin{array}{c}1.32 \pm 0.18 \\
(1.24-1.96) \\
\text { Very low to low OM content } \\
\end{array}$ & \begin{tabular}{|c|}
$5.59 \pm 0.05$ \\
$(5.50-5.66)$ \\
Soil very acidic to acid \\
\end{tabular} & $\begin{array}{c}23.9 \pm 1.72 \\
(21.1-27.0)\end{array}$ & $\begin{array}{l}214.0 \pm 33.6 \\
(147-252)\end{array}$ & $\begin{array}{c}7.31 \pm 2.22 \\
(2.86-9.7)\end{array}$ \\
\hline
\end{tabular}




\subsubsection{Climate characteristics}

Zaer region is characterized by annual rainfall variability within and among growing seasons. Dry periods are frequently associated to heat mainly during flowering and pod filling period. The mean annual rainfall in Zaer is 407 $\mathrm{mm}$ with a maximum of $664 \mathrm{~mm}$ recorded in 1978/79 and a minimum of $181 \mathrm{~mm}$ recorded in 2006/07 (Figure 3). The characterization of normal rainfall year, wet or dry year is defined by the index of Lamb "I (i)" which represents the deviation from the average normalized by the standard deviation using the following formula:

P(i): annual average accumulated during the year (i)

Pm: average of annual average accumulated during the reporting period

$\sigma:$ standard deviation annual average accumulated during the reporting period

The analysis of annual Zaer rainfall variability from 1966 to 2010 illustrated in figure 3 may elucidate the circumstances of both lentil landrace and the improved variety $\left(\mathrm{L}_{56}\right)$ introduction in Zaer area. The landrace had been cultivated at Zaer region since about five decades to meet food, environmental and economic farmers' needs. Whereas, $\mathrm{L}_{56}$ variety, thanks to its earliness, was introduced and cropped since 1995 to address the recurrence of the end

$$
\mathrm{I}(\mathrm{i})=\frac{(\mathrm{P}(\mathrm{i})-\mathrm{Pm})}{\sigma}
$$

growing season drought from 1991 to 1995.

\subsection{Zaer farmers' Agricultural Practices}

Agricultural area of Zaer represents an average of 58.6\% of total Zaer area which is mainly located in rainfall conditions [19]. The cropping system is dominated by cereals $(73 \%)$ primarily represented by soft wheat $(68 \%)$ and legumes (14.4\%) mainly represented by lentil (79\%) (Table 2) [19]. Zaer region represents an average of $26 \%$ of national lentil harvest area. The average of lentil part in legumes harvest area varies from $71 \%$ in Agh to $87 \%$ in JMB [18]. Farming crop system is highly correlated with the average of cultivated area. According to survey data, farming system is usually biennial in small scale farmers (cereals/legumes) and triennial in medium and large scale farmers (cereals/fallow/legumes).

Table 2. Farming crop system in Zaer region

\begin{tabular}{|c|c|c|c|c|c|c|}
\hline \multicolumn{2}{|c|}{ Crop/Location } & Asb & Agh & Bch & JMB & Mean \\
\hline \multirow{3}{*}{ Cereals } & Soft wheat & 66.7 & 62.5 & 71.0 & 61.1 & 67.6 \\
\hline & Durum wheat & 9.5 & 12.5 & 6.5 & 5.6 & 8.0 \\
\hline & Barley & 19.0 & 25.0 & 19.4 & 11.1 & 17.9 \\
\hline \multicolumn{2}{|c|}{ Cereals harvest area } & 68.6 & 62.7 & 75.3 & 80.9 & 72.9 \\
\hline \multirow{4}{*}{ Legumes } & Lentil & 76.3 & 70.9 & 76.8 & 87.2 & 79.4 \\
\hline & Faba bean & 6.36 & 28.4 & 5.24 & 6.23 & 8.04 \\
\hline & Chickpea & 0.42 & 0.71 & 0.52 & 0.31 & 0.50 \\
\hline & Pisum & 16.95 & 0.00 & 17.5 & 0.00 & 11.1 \\
\hline \multicolumn{2}{|c|}{ Legumes harvest area } & 15.4 & 11.1 & 13.9 & 14.4 & 14.4 \\
\hline
\end{tabular}

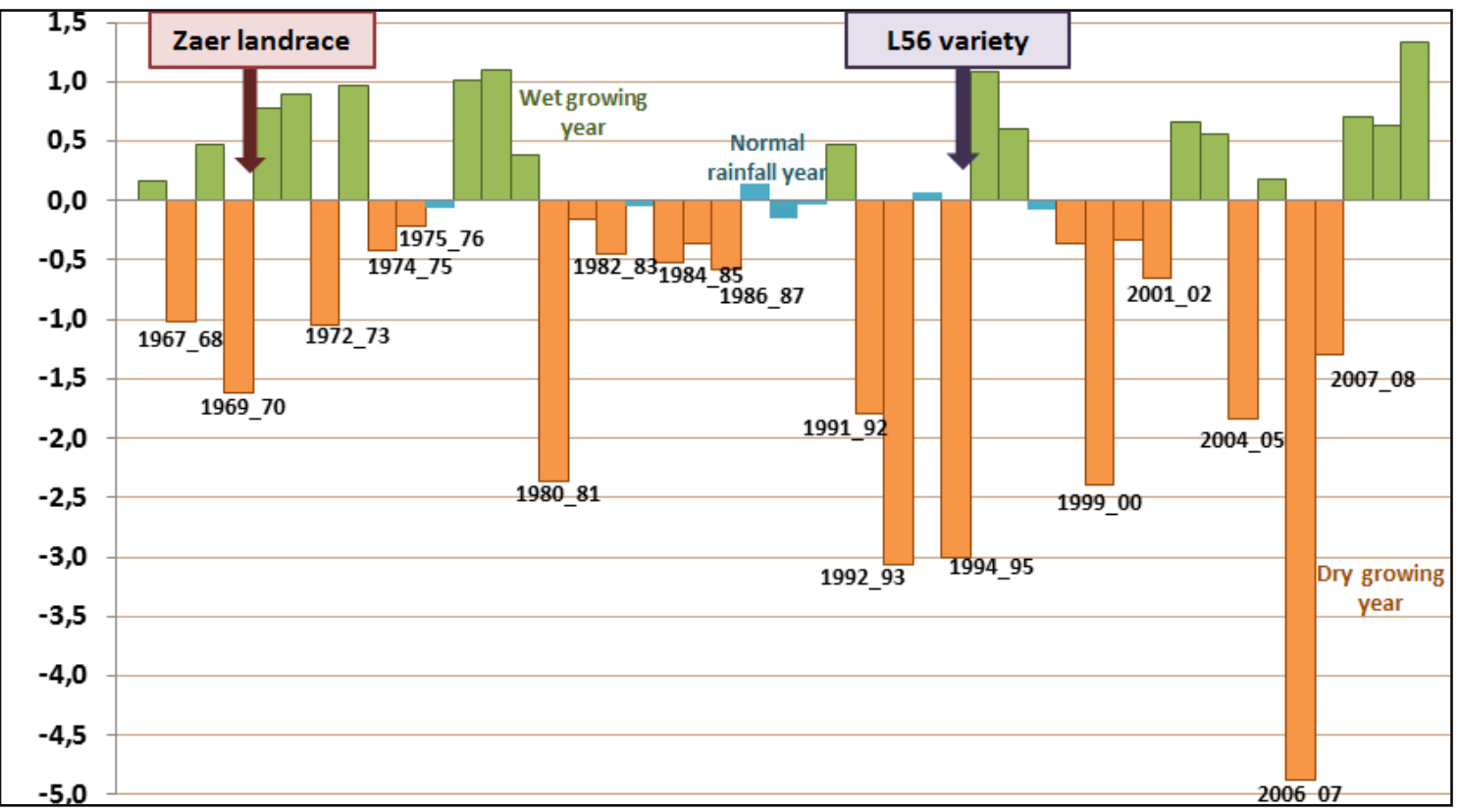

Figure 3. Inter-annual rainfall variability from 1966 to 2010 at Zaer region 
Zaer lentil is produced from two genetic resources. According to survey data, the landrace had been maintained by Zaer farmers through generations for its typical (dynamic adaptation, cooking ability and tasty quality) and heterogeneous phenotypic traits (agro-morphological and genetic diversity).

Farming practices according to survey data, depend on farmers' categories (size of cropped area) and on ecological and socio-economic environment (Figure 4). Annual average of lentil cropped area is conditioned by farmers' category and by the availability of seeds related to the previous year productivity. Seeds are always provided through informal supply system from seed exchange or local markets. Farmers produce lentil with low-input farming and the renewal seeds for the next growing season, is based on a randomized seed lot from the harvest. This practice contributes to on-farm conservation of local genetic diversity and allows dynamic adaptation to the environment constraint.

Lentil is sown between late November and early January after cereals according to the first significant rains. The sowing seed rate varies between 40 to $90 \mathrm{~kg} / \mathrm{ha}$ depending on soil texture, seed sanitary quality, seed size and sowing techniques as manual seeding or mechanical. Most of farmers supply phosphate fertilizer as Di-ammonium phosphate (DAP) mainly in fields cultivated with $\mathrm{L}_{56}$ variety.
Manual weed control is the only field management used by small scale farmers. While for medium and large scale farmers; it is usually semi-mechanical and most of them use chemical control against monocots (Figure 5). According to [20] study, weeds might reduce lentil productivity from $20 \%$ to $80 \%$. The most common fungal diseases of lentil are fusarium, rust and powdery mildew. According to survey data, chemical control is related to farmers' category, climatic growing season and yield potential. Zaer lentil is also affected by parasitic plant as broomrape and by pest as Bruchus that affect lentil production and seed quality mainly in Bch and Agh areas.

Lentils are harvested manually; one lentil harvest hectare needs in lack of appropriate mechanical harvesting, an average of nine hands' work per day which can reach up to fifteen depending on lentil productivity and weeds density. Plants uprooted are torn beaten using stationary thresher. Seeds are packaged in bags and stored in a store-part of the house generally for six months to be used for the next planting season. Seeds might be stored for two years at latest because of seed coat oxidation which reduces their market and quality value. Traditional seed storage is practiced mainly by small scale farmers to insure their food security or by some of medium scale farmers that look for increasing their incomes.

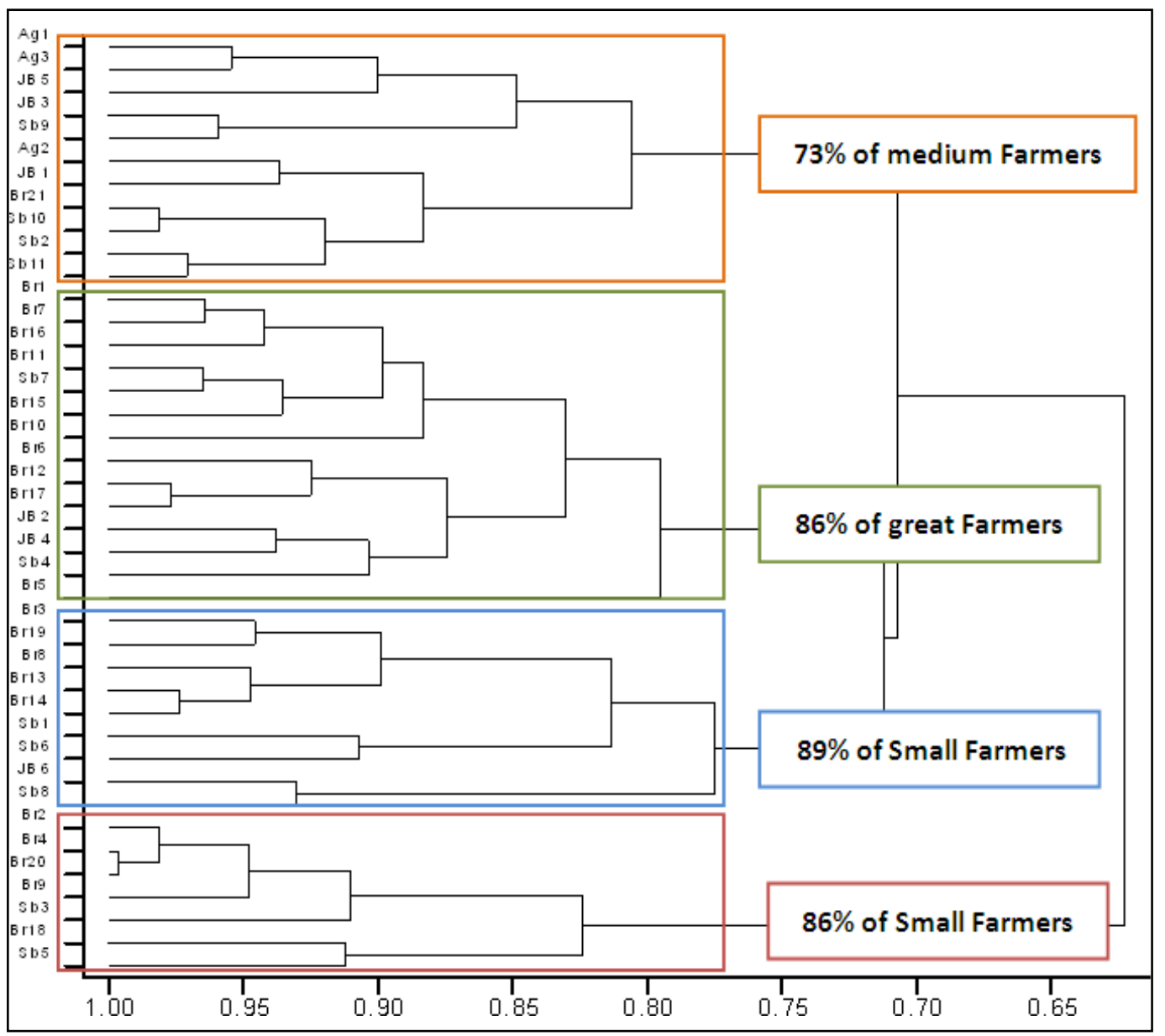

Figure 4. Farmers' groups related to farming practices 


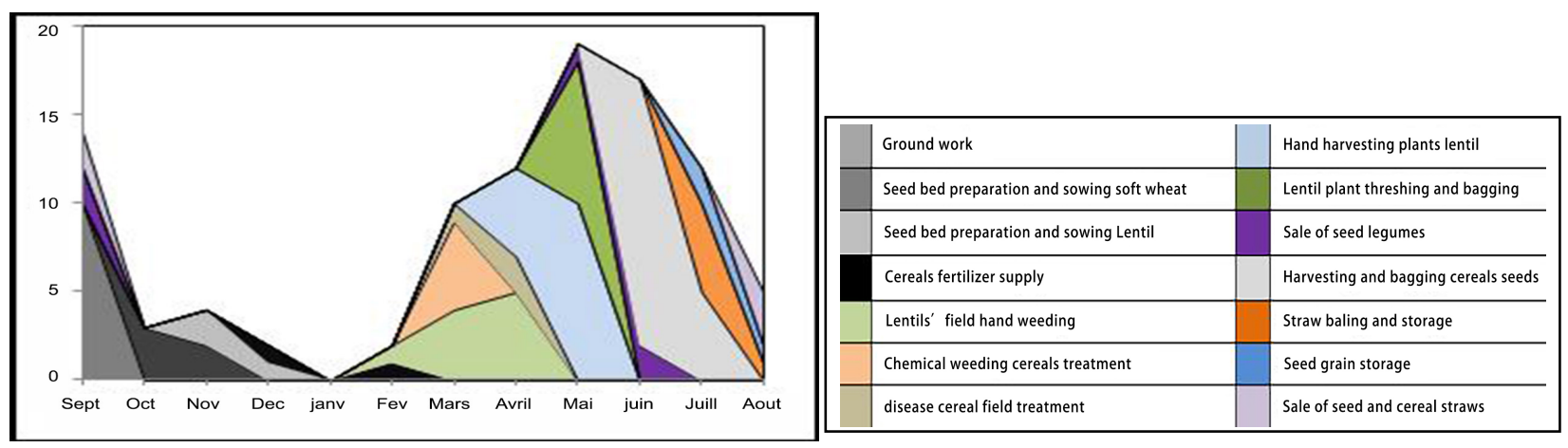

Figure 5. Zaer agricultural system according to data survey

\subsection{On-farm Conservation of Lentil Landrace}

Lentil landrace of Zaer had been maintained over generations to cope with heterogeneous agro-ecological systems and unpredictable climatic variation, to insure sustainable food need to Zaer community. According to survey data, Zaer landrace had been on-farm conserved since 1969 for its nutritional and tasty quality in addition of its ability to manage unpredictable risk of climate change. However, it is threatened because of the increase of drought incidence during flowering and pods filling period and the adoption of $L_{56}$ variety thanks to its earliness to enhance productivity and incomes.

In order to strengthen Zaer landrace conservation, current study underscore farmers' knowledge on traditional practices related to on-farm seed management and on landrace genetic diversity as suggested by [21-22]. The analysis of survey data showed that farmers generate at every growing season, landrace seeds from the harvest. They practice an empirical selection which provides them with an appropriate genetic diversity that ensures a dynamic and evolutionary adaptation to the specific environmental constraints of Zaer. This practice combines over time the effects of both natural and human selection as mentioned also by [23-28]. Thereby, the environment and farmers are the main actors of on farm conservation of the landrace. They influence its genetic diversity by promoting the most adapted lines and penalizing the sensitive ones. Landrace specific adaptation on the basis of the yield response is therefore the result of genetic diversity and environment interaction. The genetic structure of the landrace as a meta-population is shaped by both ecological environment and traditional cropping system. Moreover, many studies emphasize that genetic diversity of the accession is depending on both field size and growing season climate [29-30]. Indeed, landrace genetic diversity renewed from small-scale is less performed than landrace renewed from large-scale according to survey data. Small farmers change their seeds every two years to regenerate landrace performance which is depending on the preservation of specific genes that are involved in dynamic adaptation to stress conditions.

Otherwise, the environment such as drought and heat incidence in addition to soil degradation mainly at Agh location has decrease landrace productivity. Consequently, farmers decide gradually to adopt an improved variety $\left(\mathrm{L}_{56}\right)$ in addition or instead of their landrace thanks to its earliness. Farmers' decision may contribute therefore to gradually on-farm genetic erosion of a valuable local plant genetic resource. According to survey data, the landrace is cropped by $61 \%$ of small farmers $(<10$ ha of lentil) which account three-quarters of Zaer farmers (76\%), $52 \%$ of medium scales farmers (10-20 ha of lentil) and by $46 \%$ of large scales farmers $(>20$ ha of lentil). Thus, the landrace is on-farm conserved mainly by small and medium farmers through informal seed system management which is associated to social knowledge basis in accordance with [31-32]. Otherwise, the persistent cropping landrace by farmers attests to its agro-economic advantages than $\mathrm{L}_{56}$ introduced variety. The social value of Zaer lentil landrace according to survey data is related, to its low input requirement, its ability to reduce risk of crop failure in unfavorable climatic growing year and to its high tasty quality and cooking ability.

In this context, Moroccan's agricultural strategy (Pillar-II) had been interested on the on-farm conservation of farmers' varieties to insure food security, social and economic development mainly for smallholder farmers in changing climate [10].

\subsection{Evolutionary Processes of Zaer Lentil Diversity}

Traditional farming system has contributed for ages to evolutionary process of on-farm conservation of landraces. Developing efficient seeds system management ensures a dynamic adaptation under both environmental and farmers' practices pressures. This process allows continuously interaction with Zaer agro-ecological and socio-economic environment. Farmers are therefore the main actors in this process through varieties choice according to their yield potential and to consumers' preferences, seed production and farming practices. The informal seed system appears to be rational, dynamic and have ability to meet farmers' needs in response to stresses and consumers preferences. Seeds' dynamic involve seed supply, seed production, selection and storage taking in account farmers practices and genetic diversity of landrace at farmers' level. Traditional seed system provides farmers, at every growing season, with seeds need with potential adaptation to environment 
constraints. Farmers practice over generations a "Mass selection" as most common form of human selection. Cleveland et al. [33] reported that farmers' selection achieves significant genetic gain over generations for agronomic traits such as seed yield and yield components. This practice allows maintaining or even improving genetic diversity within accessions of the landrace depending on the genotype $\mathrm{x}$ environment interaction, the heritability of selected traits, the proportion of selection seed and seed exchange. The renewal of genetic diversity is based on the size of seed lot randomized from the lentil seed harvest. So, diversity level is depending on farmer's category and on growing year climate (Figure 6). Thus, large scale farmers produce their own seeds every year whatever the climate. They might conserve the genetic pool of the landrace. While, medium farmers produce their own seeds every year except when at least two consecutives dry years happened. They might conserve the core of landrace diversity. However, small farmers produce their own seeds only on none climatic stressed growing year playing then an important role in increasing the dynamic of genetic diversity within and between sites when the incidence of drought increases (Figure 7).

Dynamic adaptation of the landrace is depending on both its inherent genetic and biological characteristics; add to farmers' agricultural practices which maintain on-farm lentil landrace despite of $\mathrm{L}_{56}$ variety competition. Otherwise, the adopting of improved varieties may requires high inputs, farmers' dependence to seed supplies at each growing season and may do not meet consumer needs of grains cooking ability and tasty quality.

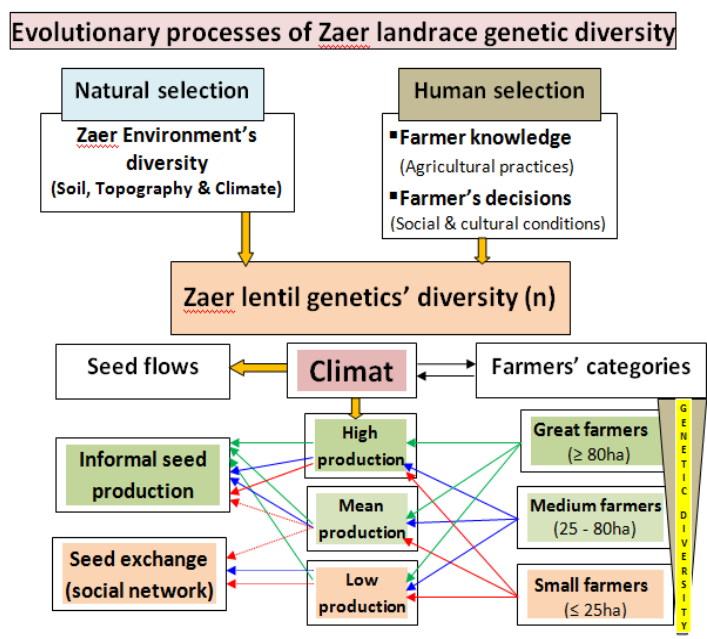

Figure 6. Seeds dynamic and evolutionary process of landrace genetic diversity

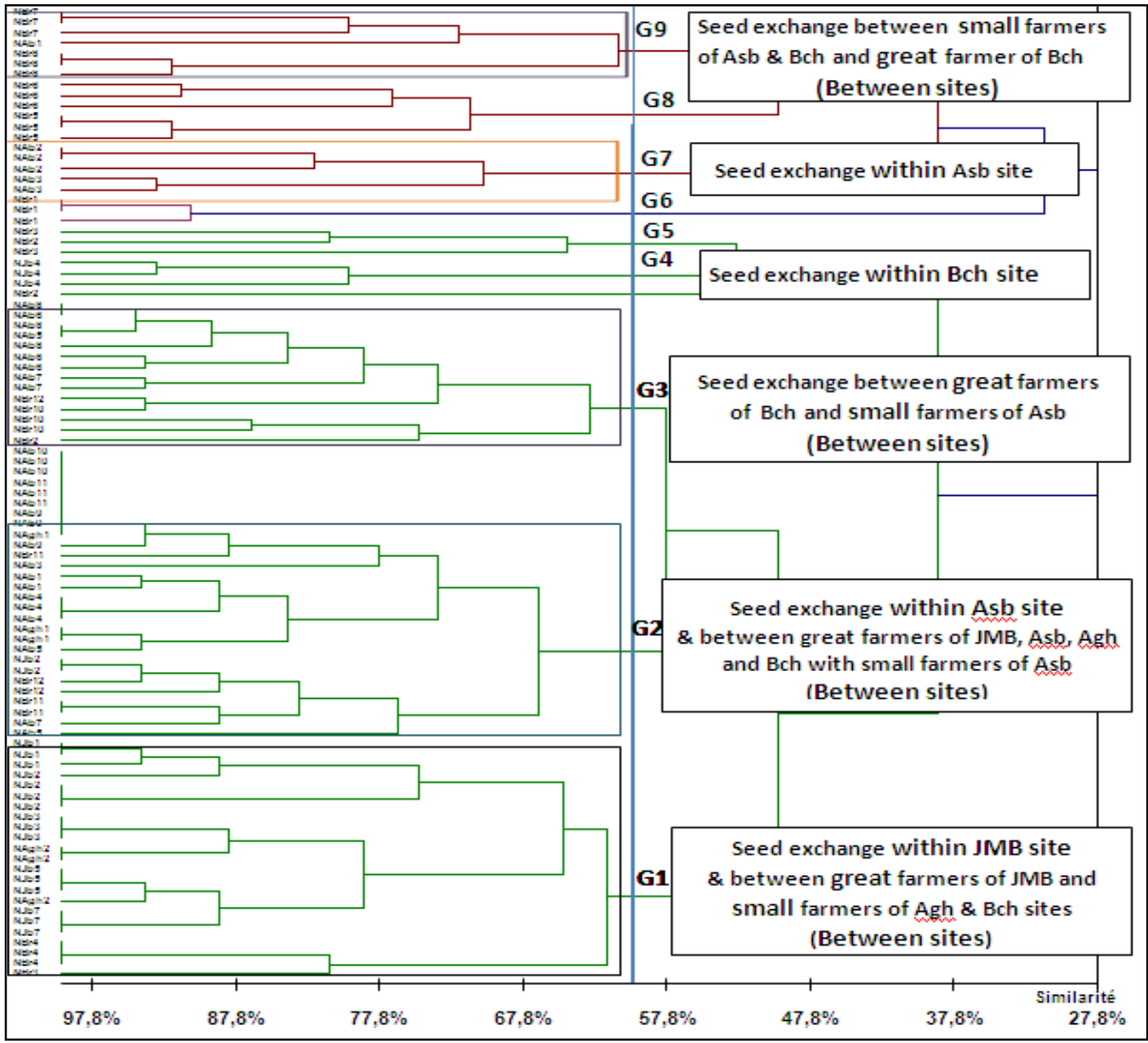

Figure 7. Seeds exchange within and between sites according to genetic analysis 
Table 3. Genetic diversity among landrace meta-population and within populations by site according to genetic parameters

\begin{tabular}{|c|c|c|c|c|c|c|}
\hline Pop & $\mathrm{P}(\%)$ & $\mathrm{Na}$ & $\mathrm{Ne}$ & SWI & $\mathrm{He}$ & UHe \\
\hline Asb & 65,22 & $1,609 \pm 0.12$ & $1,395 \pm 0.08$ & $0,336 \pm 0.06$ & $0,226 \pm 0.04$ & $0,230 \pm 0.04$ \\
\hline Agh & 21,74 & $1,043 \pm 0.13$ & $1,152 \pm 0.07$ & $0,124 \pm 0.05$ & $0,085 \pm 0.04$ & $0,093 \pm 0.04$ \\
\hline Bch & 91,30 & $1,913 \pm 0.06$ & $1,562 \pm 0.08$ & $0,479 \pm 0.05$ & $0,322 \pm 0.04$ & $0,327 \pm 0.04$ \\
\hline JMB & 56,52 & $1,478 \pm 0.14$ & $1,395 \pm 0.09$ & $0,325 \pm 0.06$ & $0,222 \pm 0.05$ & $0,228 \pm 0.05$ \\
\hline Mean & $58.7 \pm 14.37$ & $1.511 \pm 0.07$ & $1.376 \pm 0.04$ & $0.316 \pm 0.03$ & $0.214 \pm 0.02$ & $0.219 \pm 0.02$ \\
\hline
\end{tabular}

\subsection{Impact of Climate Change and the Adoption of Improved Variety $\left(L_{56}\right)$ on on-farm Conservation of Zaer Lentil Landrace}

Genetic structure of lentil landrace, as meta-population [34], results of both natural selection pressures such as ecological conditions and biotic stresses, and human selection through farmers' decisions and practices such as adopting $\mathrm{L}_{56}$ variety within informal seed production. The adaptation ability of the landrace is therefore the result of genetic diversity, environment and farming practices interaction. Thus, the on-farm conservation through generations is a dynamic form of continuous interaction and adaptation of genetic variation by natural and human selection. This process allows an evolutionary adaptation of the landrace to deal with continuing changing environmental factors (climate change and soil degradation) coupled with human selection for particularly traits in accordance with [ $[35$, $36,5,37,38]$.

\subsubsection{Natural Selection}

The increase of drought frequency at the end of growing season had a great impact on yield potential of lentil landrace related to its late flowering. Thus, climate selection had been rigorously done at mature stage for earliness lines. That might adversely affect adaptive ability of landrace and then its on-farm conservation as mentioned also by [39]. Frankel et al, [5] explains that the ability of landraces to deal with climate variability and their capacity to evolve and adapt to changing climate is related to their genetic diversity. The decrease of genetic variation within population (loss of heterozygosity) might lead to genetic drift more frequently as population size decrease [40, 29]. Furthermore, genetic population variability is correlated with seed production area size of self-pollinating species as reported by [29-30]. Indeed, the survey data and biochemical markers (SDS-PAGE) (Table 2) were efficient to confirm that evolutionary potential of lentil landrace may be limited in both small-scale farmers and high constraints environments; while great farmers might conserve the genetic pool of the landrace.

Indeed, the limited soil ability at Agh site might be behind the low productivity of the landrace. Genetic analysis using biochemical markers underline the low genetic diversity within Agh population supported by low polymorphism
(21.7\%), allele frequency (1.043), level of heterozygosis $(0.085)$ and Shannon index (0.124) (Table 3). The efficiency of genetic diversity in Agh population might be limited for adapted alleles or genes leading to its low adaptability and therefore to the risk of its genetic drift.

In conclusion, the genetic diversity of lentil landrace is continuously and significantly affected by the specific environment conditions of Zaer. Thus, genetic diversity of local genetic resources is among primary factors of the on-farm conservation.

\subsubsection{Farmer's Decisions}

The survey has provided basic information on farmers' knowledge and decision to maintain or discard their landrace. Farmers had reported their preference of local lentil variety thanks to its ability to spread crop failure, its tasty quality and cooking ability. However, yield potential is an important selection criterion for farmers leading them, in context of the end growing season drought, to adopt $\mathrm{L}_{56}$ variety for its earliness and higher yield potentials in favorable growing season. Indeed, the low productivity of the landrace due to drought or soil degradation mainly at Agh location, leads farmers to adopt $L_{56}$ variety in addition or instead of their landrace to increase the sustainability of lentil production in growing environment deterioration. They contribute therefore to further genetic erosion of a valuable local genetic resource. In this context, Borromeo et al, [41]; Cleveland et al, [33]; Jarvis et al, [39] and Maxted et al, [42] had reported that the adoption of modern varieties within traditional agro-systems is the primary cause of genetic erosion of farmers' varieties. The low productivity may be related to low genetic diversity within farmers' accessions of the landrace or to a decrease of adaptive allele's frequency mainly for small farmers' accessions in unfavorable climate growing season [36]. The biochemical markers using seed storage proteins electrophoresis (SDS-PAGE) was efficient to evaluate genetic diversity among the landrace as meta-population ( $\mathrm{P}=78 \%)$ and within population by site with polymorphism level varying from $21.7 \%$ recorded at Agh population (PS4) to $91.3 \%$ recorded at Bch population (PS2). Low genetic diversity within Agh population (PS4) threats it to genetic drift. However, the analysis showed a strong seeds exchange between Agh population (PS4) and JMB population (PS3) according to inter-population genetic 
diversification index $\left(0.023^{\mathrm{ns}}\right)$ confirmed by Nei similarity index (0.959) and by Nei genetic index (0.042) (Table 4). Seed exchange between Agh and JMB populations (Figure 7) might allow seeds renewal by increasing genetic diversity at Agh population (PS4). Seed flow intra-meta-population is often beneficial in small size populations; it could prevent the loss of genetic variability and therefore the adaptedness in agreement with [40, 43] studies.

Table 4. Evaluation of genetic diversity structure using pairwise population genetic differentiation index (PhiPT) and pairwise population Nei Genetic Distance (DG)

\begin{tabular}{|c|c|c|c|c|}
\hline Population & Asb & Agh & Bch & JMB \\
\hline & & \multicolumn{3}{|c|}{ Nei Genetic Distance (DG) } \\
\hline Asb & & 0.872 & 0.852 & 0.854 \\
\hline Agh & $0.184^{*}$ & & 0.777 & 0.959 \\
\hline Bch & $0.211 *$ & $0.169 *$ & & 0.818 \\
\hline JMB & $0.265^{*}$ & $0.023^{\text {ns }}$ & $0.217^{*}$ & \\
\hline \multicolumn{5}{|c|}{ Genetic differentiation index (PhiPT) } \\
\hline
\end{tabular}

Otherwise, some of large and medium scale farmers, taking in account economic interest, lead to adopt, in addition of their landrace, $\mathrm{L}_{56}$ variety as insurance of productivity whatever the climate. Farmers use a similar seed production technology for both improved and local varieties. Planting the two genetic bases in close proximity can foster seed flow during harvesting or post-harvest management. Indeed, the results showed a seed flow between the landrace and $\mathrm{L}_{56}$ variety according to genetic parameters (Table 5). High genetic diversity was recorded for lentil landrace of Zaer with a polymorphism level of $94 \%$, with allele frequency (1.938), level of heterozygosis (0.338) and Shannon index $(0.499)$. The $\mathrm{L}_{56}$ variety was also diversified $(\mathrm{P}=70 \%)$ as a consequent of informal seed production and seed exchange with landrace related to spatial organization of fields' production of the two genetic resources and/or to post-harvest management of seeds (Figures 8-9). Seed supply and seed management on-farm practices were effective to increase both landrace and L56 diversity. Moreover, Nei genetic distance between the landrace and $\mathrm{L}_{56}$ variety was low (0.096) that approved the exchange between landrace and L56 variety.

Table 5. Genetic diversity among and within landrace and improved variety (L56) according to genetic parameters

\begin{tabular}{|l|cccccc|}
\hline Pop & $\mathbf{P ~ ( \% )}$ & Na & Ne & SWI & He & UHe \\
\hline Landrace & 93.8 & 1.938 & 1.603 & 0.499 & 0.338 & 0.341 \\
L56 variety & 70.0 & 1.688 & 1.474 & 0.408 & 0.275 & 0.287 \\
\hline
\end{tabular}

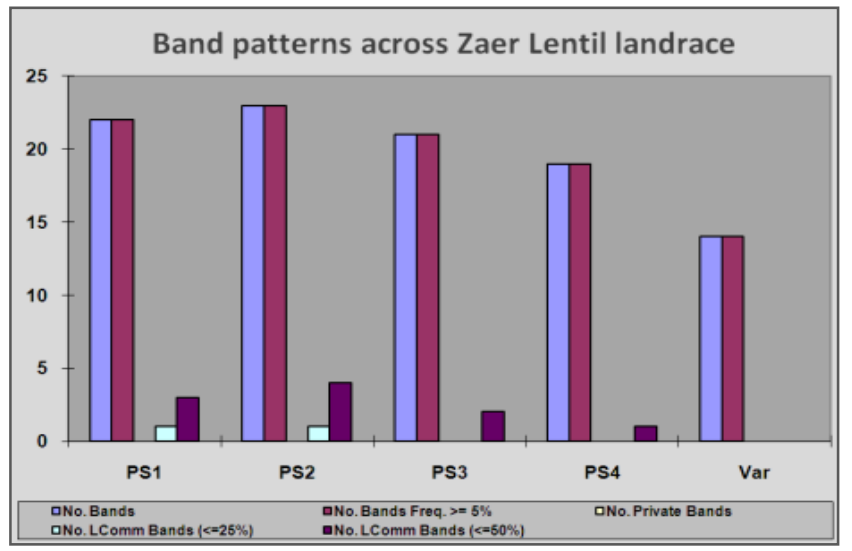

Figure 8. Zaer lentil genetic diversity landrace by site and L56 variety

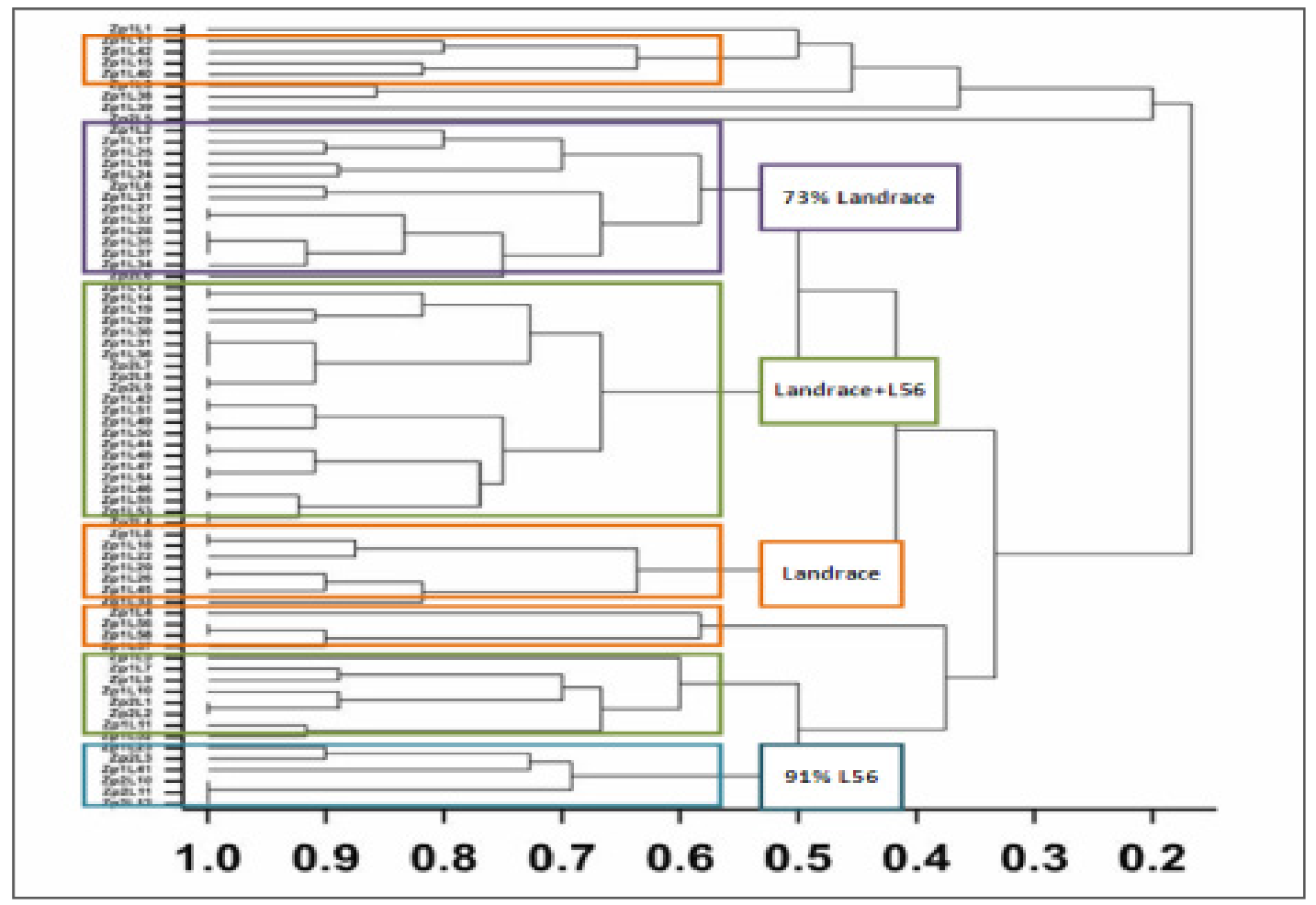

Figure 9. Seed flow between landrace and L56 variety 


\section{Conclusions}

In Morocco, farmers continue using and on-farm conserving landraces as common practices for most of lentils crop farming. Landraces are produced with low input in less favorable areas and mainly in smaller scale lands. Needless to say that dynamic adaptation of landraces depends on their genetic variability that buffer the environment stresses and optimizes therefore yield stability in those stressed environments. Most of farmers cultivate landrace to insure home-consumption and livelihood security particularly in unfavorable areas. The on-farm conservation of landraces is considerate as an approach to lead to a continued evolution of crop genetic diversity and adaptation in specific environment constraints. Otherwise, landraces represent a local gene pool which involves alleles with potential of specific adaptation and nutritional quality. They contain a large amount of useful allelic variation that might be valuable in breeding program as source of optional value of biotic or environmental stresses resilience add to potential nutritional traits. However, taking in account economic interest, the adoption of improved varieties for their superior production performance, has contribute to the loss of farmers' local varieties. Indeed, landraces are the most neglected genetic resources of human food crops.

Zaer landrace of lentil represents a cultural heritage with a significant value to local communities. It provides farmers of lentil production security with high tasty quality. The landrace had been on farm conserved as continued cropping of genetic base in traditional farming system where it has evolved. Its specific adaptation may result of the increase frequency of adaptive alleles linked to informal seed supply system. According to the survey data, genetic diversity within the landrace is one of farmers' researched factors to the on-farm conservation of the landrace.

The synthesis of survey data reveals that farmer' local variety, genetic diversity, seed production system and seed exchanges are the main components of dynamic adaptation in spatial and temporal levels. These provide farmers at every planting season, with seeds of lentil with evolutionary adaptation to variable and stressed environment of Zaer. However, in the last few years, it had been threatened to drift because of drought incidence increases and the widespread adoption of $\mathrm{L}_{56}$ variety in the landrace traditional farming areas add to the loss of indigenous knowledge. In this context, the national agricultural policy through Pillar-II of Green Moroccan's Plan (GMP), has recognized the importance of farmers' varieties in changing and stressed environments to ensure food security of local communities, improve farmers' income, and integrate small-farmers into agricultural production chain. Pillar-II proposes measures to enhance the on-farm conservation of local biodiversity within labelling local products. Present study has delighted the traditional seed system role on on-farm conservation of landraces.

The results gathered from this study were useful to suggest effective strategy to strengthen the on farm conservation of Zaer lentil landrace through optimizing (i) seed system management, (ii) seed production and seed storage conditions especially in unfavorable climates, (iii) yield stability, (iv) organization of farmers' seed exchange, and (v) valorization of Zaer lentil as high quality product. The label might enhance local product value, increase consumers' demand and marketing channels. Consequently, that encourages farmers to continue growing the lentil landrace.

\section{REFERENCES}

[1] JK. Yadav, HL. Singh, R. Kumar. Determining selection components in chickpea (Cicer arietinum L. Wilczek). Plant Archives, Vol. 3, 125-128, 2003.

[2] A. Sarker, W. Erskine, M. Singh. Regression Models for Lentil Seed and Straw Yields in Near East. Agricultural and Forest Meteorology, Vol. 116, 61-72, 2003.

[3] A. Altieri Miguel, L.C. Merrick. In situ conservation of crop genetic resources through maintenance of traditional farming systems. Economic Botany, Vol. 41, 86-96, 1987.

[4] Food and Agriculture Organization of the United Nations (FAO). The State of the World's Plant Genetic Resources for Food and Agriculture. Plant Production and Protection Division, Rome-Italy, 1998.

[5] O.H. Frankel, A.H.D. Brown, J.J. Burdon. The conservation of plant biodiversity. Cambridge University Press, Cambridge, 1995.

[6] N. Maxted, L. Guarino. Genetic erosion and genetic pollution of crop wild relatives. Proceedings of PGR Forum Workshop 5, Portugal, 2004, Genetic Erosion and Pollution Assessment Methodologies, B.V. Ford-Lloyd, S.R. Dias, E. Bettencourt (eds), 100 pages, 35-46, 2006.

[7] P. Annicchiarico. Variation for dry matter yield, seed yield and other agronomic traits in Ladino white clover landraces and natural populations, Euphytica, Vol. 71, 131-141, 1993.

[8] S. Ceccarelli, S. Grando. Environment of selection and type of germoplasm in Barley breeding for low-yielding conditions, Euphytica, Vol. 57, 207-219, 1991.

[9] L. Pecetti, G. Boggini, J. Gorham. Performance of durum wheat landraces in Mediterranean environment (Eastern Sicily), Euphytica, Vol. 80, 191-199, 1994.

[10] Ministère de l'Agriculture et de la Pêche Maritime. La Nouvelle Stratégie Agricole au Maroc (Plan Vert): Valorisation des produits de terroir, Lignes d'action du pilier II du Plan Maroc Vert. SIAM 2008, No. 8, 72 pages.

[11] P. Marchenal, M.F. Lagarde. Conservatoire Botanique de Porquerolles des variétés locales de plantes cultivées. Guide pratique, 1994.

[12] Soil survey manual, Handbook, Vol. 18, chapter 3, 1993. Online available fromhttp://soils.usda.gov/technical/manual/ print_version/chapter3.html

[13] UK. Laemmli. Cleavage of structural proteins during the assembly of the head of bacteriophage T4. Nature, Vol. 227, $680-685,1970$ 
[14] R. Peakall, P.E. Smouse. GENALEX 6: Genetic analysis in Excel, Population genetic software for teaching and research, Molecular Ecology Notes 6, 288-295, 2006.

[15] CE. Shannon, W. Weaver. The Mathematical Theory of Communication. University of Illinois, USA, 3-24, 1949.

[16] M. Nei. Analysis of gene diversity in subdivided population, proceeding of the national academy of sciences, USA, Vol. 70, No. 12, 3321-3323, 1973.

[17] GenStat Release 8 Committee. GenStat ${ }^{\circledR}$ for Windows Release 5·1, Oxford, UK, VSN International, 2002.

[18] Ministère de l'Agriculture et de la Pêche Maritime. DSS, Online available from www.statagri.agriculture.gov.ma, 2014.

[19] Ministère de l'Agriculture et de la Pêche Maritime (MAPM), Agence de Développement Agricole (ADA). Données monographiques des communes rurales de Rommani, DPA de Khémisset, CT de Rommani, 2009.

[20] J. Yenish, J. Brand, M. Pala, A. Haddad. Weed Management in Lentil. In W. Erskine, F. Muehlbauer, A. Sarker, B. Sharma, (eds). The Lentil: Botany, Production and Uses. Wallingford, UK. MPG Books Group, 326-342, 2009.

[21] N. Maxted, L. Guarino. L. Myer, E.A. Chiwona. Towards a methodology for on-farm conservation of plant genetic resources. Genetic resources and crop evolution. Vol. 49, 31-46, 2000.

[22] V. Negri, N. Maxted, M. Veteläinen. European landrace conservation: an introduction. In European landraces on-farm conservation, management and use. M. Veteläinen, V. Negri, N. Maxted (eds). Bioversity Technical Bulletin, Vol. 15, Bioversity International publ. Italy, 1-22, 2009.

[23] R. L. Barbieri, J. C. C. Gomes, A. Alercia, S. Padulosi. Agricultural Biodiversity in Southern Brazil: Integrating Efforts for Conservation and Use of Neglected and Underutilized Species. Sustainability journal, Vol. 6, 741-757, 2014.

[24] G. Laghetti, A. R. Piergiovanni, G. Sonnante, L. Lioi, D. Pignone. The Italian lentil genetic resources, a worthy basic tool for breeders. Eur. J. Plant Sci. Biotechnol., Vol. 2, 48-59, 2008.

[25] F. Mekbib, A. Bjornstad, L. Sperling, G. Synnevag. Factors shaping on-farm genetic resources of sorghum [Sorghum bicolor (L.) Moench] in the center of diversity, Ethiopia. International Journal of Biodiversity and Conservation, Vol. 1, 45-59, 2009.

[26] R. Prescott-Allen, C. Prescott-Allen. The case for in situ conservation of crop genetic resources. Nat. Resour., Vol. 23, 15-20, 1982.

[27] G. Sonnante, D. Pignone. The major Italian landraces of lentil (Len culinaris Medik.), their molecular diversity and possible origin. Genetic Resources Crop Evolution, Vol. 54, 1023-1031, 2007.

[28] R. Torricelli, D. D. Silveri, N. Ferradini, G. Venora, F. Veronesi, L. Russi. Characterization of the lentil landrace Santo Stefano di Sessanio from Abruzzo, Italy. Genetic Resources and Crop Evolution. Vol. 59, No. 2, 261-276, 2012.

[29] D. S. Falconer. Introduction to Quantitative Genetics. Longmans Sciences and Technology. Vol. 3, 437 pages, London, 1989.
[30] P.W. Hedrick, P.S. Miller. Conservation genetics: techniques and fundamentals. Ecological Applications, Vol. 2, 30-46, 1992.

[31] T. Camacho-Villa, N. Maxted, M. Scholten, B. Ford-Lloyd. Defining and identifying crop landraces. Plant Genetic Resources: Characterization and Utilization, Vol. 3, 373-384, 2005.

[32] ICRISAT, Online available from www.icrisat.org/what-we-d o/strends/nov2002.htm, 2002.

[33] D. A. Cleveland, D. Soleri, S.E. Smith. A biological framework for understanding farmers' plant breeding. Economic Botany, Vol. 54, No. 3, 377-394, 2000.

[34] I. Hanski. Meta-population dynamics, Brief history and conceptual domain. Biological Journal of Linnean Society. Vol. 42, 3-16, 1991.

[35] C. J. M. Almekinders, N. P. Louwaars, G. H. Bruijn. Local seed systems and their importance for an improved seed supply in developing countries. Euphytica, Vol. 78, 207-2 I 6, 1994.

[36] A. D. Brown. The genetic structure of crop landraces and the challenge to conserve them in situ on farm. In Genes in the field: on-farm conservation of crop diversity. S. B. Brush (ed) IDRC, IPGRI and Lewis Publishers. 3-28, 2000.

[37] N. Maxted, B.V. Ford-Lloyd, J. G. Hawkes. Complementary conservation strategies. In Plant genetic conservation: The in situ approach. N. Maxted, B.V. Ford-Lloyd, J.G. Hawkes (eds). Chapman and Hall, 451 pages, 15-39, 1997.

[38] S. Padulosi. A new international collaborative effort on traditional crops. Climate change and on-farm conservation, Proceedings of the International Conference, S. Padulosi, N. Bergamini, T. Lawrence (eds), 7-15, Frankfurt, 2012.

[39] A. Jarvis, H. Upadhaya, C. L. L. Gowda, P. K. Aggarwal, S. Fujisaka, B. Anderson. Climate change and its effect on conservation and use of plant genetic resources for food and agriculture and associated biodiversity for food security. Thematic Background Study. In The Second Report on the State of the World's Plant Genetic Resources for Food and Agriculture. Food and Agriculture Organization of the United Nations, Rome, 2010.

[40] N. C. Ellstrand, D. R. Elam. Population genetic consequences of small population size: Implications for Plant Conservation, Annual Reviews of Ecology and Systematics. Vol. 24, 217-242, 1993

[41] T. Borromeo, J. Hernandez. Philippine Rice Genetic Resources: Status, Problems and Prospects. Philippine National Conference on Genetic Resources and Development, Philippines, September 1987.

[42] N. Maxted, Z. I. Akparov, M. Arronsson, V. Negri. Current and future novel threats and opportunities facing European crop wild relative and landrace diversity. In Agrobiodiversity Conservation: Securing the diversity of Crop Wild Relatives and Landraces, N. Maxted, M.E. Dulloo, B. V. Ford-Lloyd, L. Frese, J. M. Iriondo, M. A. A. Pinheiro de Carvalho (eds). CAB International, UK, 392 pages, 2011.

[43] D. I. Jarvis, T. Hodgkin. Farmer decision-making and genetic diversity: linking multidisciplinary research to implementation on-farm. Genes in the Field: On-Farm Conservation of Crop Diversity. S. B. Brush (ed). Lewis Publishers, USA, 261-278, 2000. 